\title{
Reseña Bibliográfica de: Baltrusch, E., Kopp, H. y Wendt, Ch. (Eds.) (2016), Seemacht, Seeherrschaft und die Antike. Stuttgart: Franz Steiner Verlag. 348 pp.
}

\author{
Palabras claves: Potencia Marítima - Talasocracia - Piratería - Estados Griegos \\ - Roma
}

Keywords: Sea Power - Thalassocracy - Piracy - Greek States - Rome

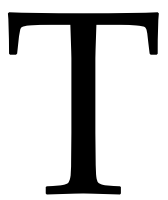

he book under discussion consists of papers presented in an international conference held at the Free University of Berlin in December 2013. It consists of an introduction written by the editors and four parts.

In the introduction, the editors explain that the expression "sea empire" (Seeherrschaft) is used unreflexibly by ancient historians and they propose to examine its validity (as well as that of other expressions). They claim that most historians tend to apply modern notions in their interpretations of this question and propose to remedy this problem. They affirm that this volume pretends to become a contribution "to a new, clearer and more conscious developed heuristic" ${ }^{\prime \prime}$ and they then proceed to explain the structure of the book. The editors conclude their introduction by stating that the book as well as the conference are intended to be a stimulus for a discussion on the concepts around the dominion of the sea.

The first part is entitled "The grip of the sea". The first chapter, on thalassocracy, was written by one of the editors, Hans Kopp. He asserts and shows that there is no agreement on what thalassocracy means and reminds readers that it was used only three times in ancient literature, once by Strabo (1.3.2 and elsewhere) and twice in scholia on Thucydides. Strabo never defines the term, nor that of the verb he derives from it, and he uses the word to designate different types of rule. The usage by the Thucydides' scholia are equally vague.

Moreover, classical authors - namely Herodotus, Thucydides, Pseudo-Xenophon and Xenophon- use the word thalassokrátor, Thucydides speaks of tò tês thalásses krátos and many others use the expression tês thalásses krateîn. Kopp proposes that Strabo was playing with words deriving thalassokratía mainly from demokratía but meaning, not the power of the sea, as in the model, but either the power over the sea or victory at sea. He concludes by saying that only in the 16th century was thalassocracy integrated into

\footnotetext{
${ }^{1}$ Baltrusch, Kopp and Wendt (2016, p. 18).
} 
modern languages under the impression that their users were recurring to a more direct authentically ancient term and says that a modern term such as Seeherschaft, rule or dominion over the sea, would be more appropriate and authentic.

The second chapter bears the title "The sea in the ancient geographers". It was written by Michael Rathmann. The author observes that ancient geographers and historians tended to contemplate the sea from the coast, never from the open sea. Besides, they knew well the whole extent of the Mediterranean, named by Pliny mare internum or mare nostrum, but obviously not that of the Atlantic and Indian Oceans. They measured the distances on sea always with reference to points on land and they always sailed by the coast and only exceptionally by the open sea. Periploi were not handbooks intended to assist navigation, for that, captains needed people who knew the sailing route. Maps also did away with the deep sea and concentrated on the coasts as the Tabula Peutingeriana shows. The authenticity of the Artemidorus papyrus is denied without one word on it. The author concludes that geography was a description of land, not of the sea.

In the third chapter, Christian Wendt begins by quoting a passage from Saint Augustine (civ. 4.4) in which an anonymous pirate tells Alexander the Great that the only difference between himself and the king is the scale of their respective enterprises, and Wendt then quotes Tacitus stating what the Briton leader Calgacus (Agr. 30-32) said about Romans devastating a country and calling its results peace. The problem is that the only factor Wendt omits is that precisely the scale confers legitimacy, so that Dareios III, the lawful king of kings, had to run away until he was killed by one of his satraps for no other reason that because his defeat by Alexander himself had impaired his legitimacy, while confirming the Macedonian's. At the end of the introduction, Wendt says he will explore this relation between piracy and sea power in three authors (Thucydides, Polybius and Cicero). He claims they have no theory on the subject, and ignores his own ideological operation of blurring the limits between legal and illegal actions up to this point.

However, when treating Thucydides, he does mention that Minos and Corinth received legitimacy as they gained control of the sea and rid it of pirates, in the first case "factually, in no way morally or a priori". ${ }^{2}$ Of Polybius, we learn that the expulsion of Illyrian pirates from the Adriatic resulted in legitimacy for the Roman Empire. Finally, Cicero affirms that by ridding the whole Mediterranean of pirates, Rome has confirmed its status as a world power. Wendt draws the conclusion that by denying this, Calgacus denied the civilizing process of Roman conquests. The only thing is, I think, that it was Tacitus who reported it, not Calgacus himself, and that his witty saying was of no consequence in the Roman dominion of Britannia. The author concludes that states need pirates in order to acquire legitimacy for themselves and says that historians should be

\footnotetext{
${ }^{2}$ Wendt (2016, p. 83).
} 
aware of "how difficult it is to divide information from attribution in the sources". ${ }^{3}$ But all legitimizing discourses have the same difficulties and all discourses inform and attribute qualities, even of course Wendt's. Not all accusations of piracy are equally invalid and piracy in antiquity was more than an accusation from states and its combat not only a way to acquire legitimacy, but also a defense of the state and its inhabitants from criminals.

In his chapter on "Thucydides, Polybius and Mahan on Sea Power", Barry Strauss states that, at the wake of the Spanish-American war which, as is well known, ended in the conquest of practically all remaining Spanish colonies by the United States, Alfred Thayer Mahan exposed the idea that sea power was decisive for the control of the world and took Britain as an example. It was said at the time that he shared this idea with Thucydides, but if examined closely, although the ancient historian understood and explained the importance of naval war, he disliked sailors and the democratic Athenian constitution in which they and the rowers participated. Polybius also explained that Rome won the First Punic War when she turned to the sea and defeated the Carthaginians on it, but he also preferred land war and armies.

Thus ends the first part. The second bears the title "Operative Conceptions". Raaflaub starts by reminding Herodotus' tale, according to which Thales of Miletus, when the Ionians were about to be incorporated to the Persian Empire, advised them to convene a common Ionian council based on the island of Teos and to turn the poleis into demes. He compares this with Cleisthenes setting up demes in Athens, but this case is different, Athens being already a unified state with its council. In any case, the author proposes to look at the concepts the ancients used to name what moderns called the Delian League (Attisch-Delischer Seebund). The author traces the history of the League and the way Athens tended to increase its power within and says that, in order to name this process, concepts should be explored first.

Raaflaub claims that at the aftermath of the Persian wars, Athens planned to build an alliance but little by little it was gradually more centralized so that it became an arché which claimed enormous costs and innovations, but it never occurred to the Athenians to create mechanisms to integrate the allies into a state larger than a polis. The concession of citizenship remained an exception and the rules to acquire it were hardened as sons of non-Athenian mothers were excluded. Democracy favoured the arché as thétes became rowers and worked at the dockyards, while paying for participation in politics favoured the poors' presence in tribunals and the council and devolved power to the assembly at the expense of that very council. This led to aggressiveness, and eventually to war with Sparta, but never to the idea of establishing a larger state. Thales' ideas as expressed by Herodotus as well as those he attributed to Bias of Priene that the Ionians should migrate to Sardinia and found there a new polis (1.170.1-2), as well as those expressed by Lysistrata in the comedy when she proposes to let foreigners participate in a discussion

\footnotetext{
${ }^{3}$ Wendt (2016, p. 91).
} 
on ways to regain peace belong to the 5 th and 4 th centuries. These are the testimonies of ideas on the creation of larger states in the Classical period. He then discusses how the Athenian state should be named and opts for arché and then argues that if German must be used it should be Herrschaft, which in English would be rule or dominion. Anglophone ancient historians, as Raaflaub recognizes, tend to use empire. Personally, I think that using Greek words when they cannot be accurately translated would lead to an isolation from common readers, who would have to know Greek better than their respective native languages. Raaflaub then compares Athens with Rome. The Italians increased their state by the surrender of the overcome enemies, the absorption of some of its land and the cooption of the élite, all of which was unthinkable in Greece and so the creation of a bigger state was conditioned by the existence of the polis.

Raaflaub then treats the Boeotian Confederacy. Its way of functioning is explained in the Hellenica Oxyrrinchia. The region was divided into districts, which sent representatives to four councils. These councils received the right to fix the agenda of the assemblies. The number of representatives each polis had depended on the number of its inhabitants. The confederacy existed several decades until its dissolution under the king's peace (386 BC), but he omits to say that it was restored seven years later and lasted centuries. The Boeotian example represented no alternative to Athens, since her allies were not ethnically homogeneous, and her allies were all dispersed in the Aegean Sea and its coasts.

Finally, Raaflaub discusses the second Athenian League, which tried to protect all the allies from Athens but failed when Sparta lost its hegemony over Greece. He does not discuss the Hellenistic leagues, and only observes that they guaranteed their members' autonomy which is famously not the case of Sparta in the Achaean Confederacy, which led to the Achaean war and the dissolution of the confederacy. Raaflaub finishes by reminding that the common peace guaranteed liberty and autonomy and that these values prevented Greek poleis from forming larger states. The reader gets the impression that Raaflaub thinks this a defect but who can tell that the citizens' happiness depends on the size of their states?

Julia Wilker proposes to analyse the Athenians' perception on sea-power during the fourth century B.C. and announces that her main source will be the orators. She affirms that after defeat at the sea battle of Aegos Potamoi the Athenians believed that their polis could only be defeated by sea and in the fourth century they tried, with financial difficulties, to ensure safety in the Aegean and the continuous grain provision from the Black Sea. She quotes Isocrates, who in his Panegyricus asserted that Athenian hegemony had combatted piracy and was advantageous to every part. The formation of the second Athenian league shows that eastern Aegean poleis feared the newly reestablished Persian power over Ionia and for the Athenian it was a question of prestige rather than of enrichment. She then quotes a speech attributed to Demosthenes (On Halonnesus 6) where the orator proposes to reject an offer of Philip II proposing to give the Athenians 
back the island which gives its title to the oration. Halonessus had been conquered from pirates by the Macedonians and the orator states that Athens has the exclusive right to preserve peace and security in the Aegean, therefore, the Macedonian conquest was illegal and therefore its cession to Athens also. In a note, Wilker concedes that Aeschines blamed Demosthenes for the war against Philip, but she omits saying that there was a pro-Macedonian faction in Athens, and that thus there was no unanimity among the Athenians on the subject of sea-power. ${ }^{4}$ However, she finishes by reasserting that seapower was part of the Athenian identity even after Chaeronea. Certainly the existence of factions persisted, even if some were more articulate than others.

Raimund Schulz begins his chapter on "The sea in the strategic thought of the Roman republic" by stating that Rome started late to develop a military fleet and adds that she was forced by the necessity imposed by foreign relations. Rome acquired a military fleet as a consequence of the conquest of Antium in 334 B.C. Already by then the city was large enough to need to import grain from Sicily and control its transport. Rome won the Punic Wars because it could man more ships and control strategic ports at Sicily, Sardinia, Corsica, and Illyria and she was thus able to prevent Philip V from joining Hannibal. Already during the Second Punic War Rome needed to import grain from Egypt and a year after its end she began to intervene in Greece and proceeded to dominate the Aegean as well as the Eastern Mediterranean after expelling the fleets of the Hellenistic kingdoms and striking an alliance with Rhodes and Pergamum. At that point, pirates posed no problem, for they belonged to the trade of the Eastern Mediterranean, but in the 60s B.C. they extended their actions to the whole sea and began to interfere with the grain supply of Rome. By the early 60s the Romans had made provinces of all the territories around the sea except Egypt and later in that decade Pompey managed to expel pirates totally, except his personal clients, and established a global sea power over the whole Mediterranean with the help of Rome's allies. During the civil war, both Pompey and his son Sextus Pompeius threatened to conquer Rome from the sea and caused hunger among the Romans, but Caesar and Octavian built more ships than Sextus Pompeius had and, lastly, Agrippa defeated with small ships the massive ones that Anthony brought to Actium, and Rome became the first power which managed to dominate the Mediterranean basin and its sea.

Bernhard Linke poses the question of how could Rome manage to recruit enough rowers to man the fleet with which she defeated the Carthaginians in the First Punic War. He says that there were three options for recruitment in the pre-modern era: by force, by compensation with booty or by the granting of rights. He argues that Rome used force at first, but his sources are Cassius Dio and Zonaras. Must I remark that they wrote the former hundreds and the latter more than a thousand years after the fact? Linke says that the Romans later opted for promises of booty. In general, he seems to

\footnotetext{
4 See, for example, Mossé (1975, p. 55-58).
} 
attribute the same credibility to Polybius and Livy, the nearest sources, as to Eutropius and Orosius. In 247, still during the First Punic War, Rome's popular assembly decided not to pursue the war by sea, instead particular citizens embarked upon privateering until 242, when it was decided that private citizens would pay for a fleet commanded by a Roman magistrate. Eventually, this fleet destroyed a Carthaginian one and achieved victory in the next year. After the war, Rome deprived the Carthaginians from Sardinia and conquered Corsica, and they erected the first provinces. In the twenties of the III century they struck a treaty with Hasdrubal, who had extended a Carthaginian province in Spain. It fixed the limits of influence of the signatories at the river Ebro. The spectacularity of Hannibal's land campaign has detracted from the appreciation of maritime combats in the Second Punic War. First a Roman fleet destroyed the Carthaginian at the Ebro's mouth and then a larger fleet transported Roman troops to Africa. The lex Claudia was promulgated, which forbid senators to have large transports boats and therefore favoured rich non-senators. After the war, the Romans dispensed from a large fleet for fear of intensifying class differences among the citizens.

The third part bears the title of "Boundaries of the canons" and treats of sea power exercised by states which are not generally conceived as primarily deprived of navies.

The first state to be treated is Sparta. With reason, Martin Dreher states that it was Thucydides who ascribed to Pericles (hardly his hero, though) the remark that Athens dominated the sea and Sparta the land at the beginning of the Peloponnesian War. He then lists all of Sparta's naval enterprises during the archaic period beginning with Tarentum's foundation in the eighth century, and then he tells of Sparta's command of the Greek League's fleet against the Persians, which prove Spartans were not ignorant of sea combat. Afterwards, he reminds the readers that Thucydides tells how the Athenians destroyed the Spartan dockyards in 455. At the start of the Peloponesian War, Sparta appointed a commander of the ships (nauarchos) with authority also on the allied navies, but they were systematically defeated by Athens until in 412, when the Spartans obtained subsidies from the Persian empire, managed to build two hundred ships and destroyed the Athenian ships in a land battle in Aegos Potamoi and gained the hegemony over the sea. This situation lasted till 394. As is well known Sparta's role as a Peloponnesian power was ended at Mantinea by Epaminondas in 371.

Monika Schuol begins her discussion of Judaean sea power by contrasting the testimony of Josephus, who says that Judaeans had no relation to the sea with that of Philo, who affirms that they are a seafaring people. She then sets to revise the history from the age of the kings to the Judaean revolts against the Romans. During the existence of the Judaean states before the Babylonian captivity, the Judaeans disposed of no ports on the Mediterranean and only one on the Red Sea. They cultivated overseas trade through or with the Phoenicians. Only in the Hellenistic age did Judaeans emigrate to coastal cities. As a result of the Maccabeans' revolt the Judaeans recovered independence (145) and expanded at the expense of the Seleucid state until they possessed the 
Palestinian coast and could engage in maritime trade and piracy. This ended in 67 , when Pompey reduced Judaean territory to Judaea, Galilea and Perea and subordinated it to the new province of Syria. After Actium, Augustus devolved the coast to the client king Herodes Agrippa, who refounded Strato's Tower as Caesarea Palaestina, a Hellenistic port with military boats. The city became an important port which connected Egypt and the Asiatic interior with the west; it became the capital of the Judaea province. During the Judaean revolts against Rome Caesarea became the Roman headquarters. After Jerusalem's fall some Judaeans captured the port of Joppa and seriously interfered with trade from Egypt until the city was recovered by the Romans and most pirates died in a sea storm. Therefore, Schuol concludes that there was no Judaean sea power.

The fourth and last part of the book is devoted to "Self-perception and representation". Its first chapter, by Sabine Müller, treats the Persian Empire. Her main sources are Persian inscriptions. Since Cyrus II conquered Babylon he was represented as having influence on both the upper and lower seas, meaning the Mediterranean and the Persian Gulf and, later on, when Cambyses II conquered Egypt he had recourse to a fleet which in addition conquered Cyprus. Müller asserts that only the Behistun inscription handles a real political event while the others only express imperial ideological and symbolic ideas, but he never explains what that real political event was. The ideological parts present the king as the responsible for order in the world. If this is not hybristic, as Müller concludes, I could not call it otherwise.

In her chapter on "Delos as center of Athenian 'sea power'- An archaeological perspective", Monika Trümper sets out to synthesize how "permanent [architectural] structures ... potentially served to symbolize and commemorate Athenian power and interest" ${ }^{5}$ It is not clear which buildings did Athenians erect in their first period of domination (478-314 B.C.). While in the second period (167 on), in any case, there seems not to have been enough space to document Strabo's testimony of Delos as a large port and no ships could stay at such a shallow port as Delos then was. The presence of many shops is ambiguous. Trümper then explains that archaeologists are not in agreement as to the chronology of the buildings and concludes that "currently, it is still difficult to assess what kind of power Athens had over the free port and how this would have been visible in the urban landscape". ${ }^{6}$

Daniel Kah writes on "Rhodes as a seapower". He starts by stating that the sources are abundant because there are the histories by Polybius and Livy and many inscriptions, of which many are "CV inscriptions", as Ma called them. The island became important as a sea power when its three poleis unified at the end of the fifth century, but they were never able to control the Aegean and the maximum ships they could man were 60 or 75 at the Syrian war. After the Third Macedonian war Rhodes incurred in Rome's wrath because of what was deemed as the insufficient and unenthusiastic

\footnotetext{
5 Trümper (2016, p. 234).

${ }^{6}$ Trümper (2016, p. 251).
} 
participation of the island as an ally. Therefore, a treaty was struck which reduced its independence, though it kept a navy until the Flavian dinasty. Kah concludes that around 300 there ceased to be a hegemonic state in the Aegean and that Rhodes was the last polis to assert its presence in that area, but that it was unable and even unwilling to rid it of pirates.

In her fascinating chapter on "Space, vision and the friendly sea. Scipio's crossing to Africa in Livy's book 29", Virgina Fabrizzi demonstrates that Livy was a writer of genius. She analyzes how the Roman historian tells about Scipio's departure to and landing in Africa and describes it as a campaign favoured by the gods and anticipating Roman victory. Fabrizzi then compares it with Hannibal's subsequent crossing which, on the contrary was full of omens which announced the Punic defeat.

The last chapter uses a quotation from Martial as part of its title "'Here was precisely land' - Naumachies in Rome". It was written by Ernst Baltrusch. He rightly claims that "politics must (also) be a show". ${ }^{7}$ He adds that Roman statesmen from Julius Caesar have staged their success and power through the representation of sea battles at Rome (or nearby) and he proposes to examine the subject after posing some questions. He then describes all naumachies from that of Julius Caesar to that of Trajan, this last with less detail. He shows that the emperors endeavoured to demonstrate their power over land and sea.

The book contains a bibliography of twenty seven pages, an index of concepts and names extending over twelve pages, and a short curriculum of the contributors. It succeeds in presenting a discussion of concepts and it will be of interest not only for students and professional ancient historians, but for everybody interested in naval power and the use of historical concepts.

\section{Bibliographical references}

Mossé, C. (1975). Le Ive siècle (403-336). In E. Will, C. Mossé and Goukoswky, P. (Eds.), Le monde grec et l'Orient. II. Le IVe siècle et l'époque hellénistique (pp. 9-244). Paris: Presses Universitaires de France.

Ricardo Martínez Lacy

Universidad Nacional Autónoma de México lacy@unam.mx

Para citar esta reseña:

Martínez Lacy, Ricardo (2018). Reseña Bibliográfica de: Baltrusch, E., Kopp, H. y Wendt, Ch. (Eds.) (2016), Seemacht, Seeherrschaft und die Antike. Stuttgart: Franz Steiner Verlag. 348 pp. Anuario de la Escuela de Historia Virtual, 13, 106-113.

\footnotetext{
${ }^{7}$ He uses this word in English; Baltrusch (2016, p. 291).
} 